J. Product. \& Dev., 18(1):37- 46(2013)

\title{
EFFECT OF HORMONAL TREATMENT ON RABBITS OVARIANS RESPONSE, NORMAL EMBRYOS PRODUCTION AND IN VITRO EMBRYO DEVELOPMENT POST-THAWING
}

\author{
Samia Z. Meshreky, Aboul-Ela H.B., Hoda A. Shabaan and Samya E. Ibrahim \\ Animal Production Research Institutes, Agriculture Research Center, Dokki, Geza, Egypt. \\ Corresponding author: Samia_meshreky2010@hotmail.com
}

\section{ABSTRACT}

The effect of eCG dose injection on rabbits ovarian response, normal embryos production and in vitro survival of embryos after vitrification -thawing were examined. Forty-one of multiparous New Zealand White $(N Z W)$ rabbits (12 month of age, $3.87 \pm 0.16 \mathrm{~kg}$ average body weight) were used as embryo donors, allotted in three groups. Does of the $1^{\text {st }}$ group $(n=21)$ were injected intramuscularly with $20 \mu \mathrm{g}$ GnRH/doe for induction of ovulation and artificial insemination (control). Embryo donors in the $2^{\text {nd }}$ and $3^{\text {rd }}$ groups ( $n=10 /$ group) were administered intramuscularly with 20 or 40 eCG IU/kg live weight (superovulation), 68 $h$ before artificial insemination. Immediately prior to insemination, the does were injected intravenously with hCG at $40 \mathrm{IU} / \mathrm{kg}$ live weight. All does were slaughtered at 48-50 $h$ after insemination. Embryos were recovered, counted and evaluated for their stage of development, morphological appearance then vitrified. Post 48 h storage in liquid nitrogan $\left(L N_{2}\right)$ at $-196{ }^{\circ} \mathrm{C}$, embryos were thawed and cultured in vitro with Ham's F10 medium supplemented with $20 \%$ FCS for two days.

Results showed that donors treated with 20 or $40 \mathrm{IU}$ eCG/kg live weight produced significantly $(P<0.01)$ more CLs, haemorrhagic follicles and yielded three to four folds embryos/doe when compared with GnRH (control group). Embryos recovered from does treated with GnRH (control group) reflected a higher fertilization rate $(96.6 \%)$ than those recovered from does treated with 20 (89.4\%) or 40 (84.1\%) IU eCG/kg live weight. The percentage of morphological normal embryos recovered from donors injected with 20 or $40 \mathrm{IU}$ eCG/kg live weight (84.9 or $77.0 \%)$ was significantly $(P<0.05)$ lower than that obtained from the normally ovulated does (97.4\%). Donors treated with $40 \mathrm{IU}$ eCG/kg live weight retard the rate of embryonic development and reduced their diameters more than those injected with $20 \mathrm{IU}$ eCG/kg live weight compared to GnRH (control group). In 40 IU eCG treated donors-vitrified embryos group, only 61 from 147 embryo vitrified-thaw reached blastocysts (41.5\%), whereas 112/186 $(60.2 \%)$ in 20 IU eCG treated does compared to $74 / 111$ (66.7\%) in control group. The present study demonstrates that doe rabbits treated with $20 \mathrm{IU}$ eCG/kg live weight provides superior embryos survival rates than those 
treated with $40 \mathrm{IU}$ eCG/kg live weight for rabbit embryos production manipulation studies and gene bank.

Key words: Hormonal Treatments, Ovarian Response, Rabbit Embryos, Vitrification.

\section{INTRODUCTION}

Ovulation in doe rabbits can be induced by exogenous GnRH administration intramuscularly or intravaginal (Rebollar et al., 2012). Superovulation of rabbits is commonly used to synchronize estrus and to increase the number of oocytes or embryos for various reproductive and embryo manipulation studies. A single injection of PMSG (eCG) at dosages from 40 to $150 \mathrm{IU}$ has been frequently used for the induction of superovulation (Schmidt et al., 1992) for collection of embryos for in vitro studies. For most domestic animals, the responses to superovulation treatments are not controlled as a consequence of the lack of knowledge on exogenous gonadotrophins effects on the ovarian function (Salvetti et al., 2007). Structurally intact embryos and high morphological quality grade may be essential components for successful rabbit embryo cryopreservation. The induction of ovulation in mammals by administration of exogenous gonadotrophin may be responsible for an increased incidence of chromosomal abnormalities in the resulting embryos. Fujimoto et al. (1974) noted slight, but statistically insignificant, increases in chromosomal abnormalities in rabbit blastocysts and intratubal embryos obtained after superovulation, when compared with a control group. Only the eCG dose was varied because the work of Shaver (1970) had indicated that variation in HCG dosage apparently did not affect the chromosome constitution of rabbit embryos.

Therefore, the aim of this study was to compare the ovary response, fertilizing aptitude, morphological normal embryo production and their developmental stage pre- and post - vitrification of multiparous does treated with having received during their whole reproductive career, 20 or $40 \mathrm{IU}$ of eCG/kg live weight compared with $\mathrm{GnRH}$ injection.

\section{MATERIALS AND METHODS}

This experimental work was carried out at the laboratory of Reproduction and Biotechnology located in Animal Production Research Institute, Agricultural Research Center, Ministry of Agriculture, Egypt.

Forty-one of multiparous New Zealand White rabbits (at 12 month of age, $3.87 \pm 0.16 \mathrm{~kg}$ average body weight) were used as embryo donors in the present work. Animals were housed in individual metal cages for 3 weeks prior to hormonal treatments to eliminate the chances of pseudopregnancy. The animals were kept under controlled 16h light: $8 \mathrm{~h}$ dark photoperiod and fed adlibitum with a commercial pelleted diet contained $17.5 \%$ crude protein, $13.6 \%$ crude fibers and $2.5 \%$ fat. Fresh potable water was made available all times through stainless nipples. 
eCG donors treatments, embryo collection and evaluation:

Forty one NZW does rabbits were used as embryo donors and allotted into three groups. Does of the $1^{\text {st }}$ group $(n=21)$ were treated with intramuscular injection of $20 \mu \mathrm{g} \mathrm{GnRH/doe} \mathrm{for} \mathrm{induction} \mathrm{of} \mathrm{ovulation} \mathrm{and} \mathrm{artificially}$ inseminated. Embryo donors in the $2^{\text {nd }}$ and $3^{\text {rd }}$ groups $(n=10 /$ group) were administered intramuscularly with 20 or 40 eCG IU/kg live weight (Folligon, Intervet, International B.V. Boxineer-Holland), $68 \mathrm{~h}$ before artificially insemination. Immediately prior to insemination, the does were injected intravenous with hCG (Pregnyl, Organon, Nile Co., Egypt) at $40 \mathrm{IU} / \mathrm{kg}$ live weight. The does were inseminated with semen collected from fertile bucks for the same breed. All does were slaughtered at $48-50 \mathrm{~h}$ after insemination. The reproductive tract (oviduct and uterine horns) were removed and embryos were recovered by flushing twice with $5 \mathrm{~mL}$ of Dulbecco's Phosphate Buffered Saline (®DPBS, (PBS: Gibco, Cat. No 21300-017, UK) supplemented with $\mathrm{CaCl}_{2}(0.132 \mathrm{~g} / \mathrm{L}), 0.2 \%$ of bovine serum albumin (®BSA, Sigma Chemical Co., St. Louis, Mo, USA) and antibiotics $(10,000 \mathrm{IU}$ Penicillin G potassium+ $10 \mathrm{mg}$ streptomycin sulfate $/ \mathrm{ml}$, Sigma) at room temperature $\left(20-25^{\circ} \mathrm{C}\right)$. After recovery, embryos and oocytes were washed twice in fresh DPBS supplemented with 10\% FCS and antibiotics, counted and evaluated for their stage of development, morphological appearance and their physical measurements under stereoscopic microscope. Embryos with no abnormalities in mucin coat, zona pellucida and with homogenous blastomeres were scored as excellent and good embryos (grade 1 or 2) according to International Embryo Transfer Society classification. Embryo diameters, excepting ZP, were measured from the same images on the screen of the monitor using scale bar micrometer, which was previously calibrated on a $\times 40$ objective and $\times 10$ eyepieces.

\section{Vitrification and warming of embryos:}

Morphologically normal embryos (grade 1 or 2) were vitrified using procedure described by Vicente et al. (1999). The cryoprotective solution was a $1: 1: 2$ solution (v/v/v) of dimethyl-sulfoxide (3.5 M DMSO, Sigma), ethylene glycol (4.4 M EG, Sigma), in DPBSCa (DPBS supplemented with $0.132 \mathrm{~g}$ $\left.\mathrm{CaCl}_{2} / \mathrm{L}\right)$ supplemented with $0.2(\mathrm{w} / \mathrm{v}) \mathrm{BSA}$ per liter of cryoprotective solution. Vitrification was carried out in two steps. First, embryos were pipetted into 0.2 $\mathrm{ml}$ of PBS medium and placed in a culture dish and then $0.2 \mathrm{ml}$ of the cryoprotective solution was added and agitated. Embryos were kept in this medium for 2 minutes. In the second step, $0.6 \mathrm{ml}$ of the cryoprotective solution was added and quickly agitated. Then, embryos suspended in the final vitrification solution were loaded into $0.25 \mathrm{ml}$ plastic straws (IMV, L'Aigle, France), sealed with polyvinyl-alcohol sealing powder and plunged directly into liquid nitrogen. The exposure time of embryos to the final vitrification solution did not exceed 1 minute. The two vitrification steps were carried out at $20{ }^{\circ} \mathrm{C}$. The straws contained three sections separated by air bubbles. The first consisted of PBS in the cotton plug, the second section contained the embryos suspended in vitrification medium $(0.1 \mathrm{ml})$ and the third section consisted of PBS. The straws 
were sealed and identified. Each straw held between 5 to 8 normal embryos. The straws were stored in liquid nitrogen for two days. Devitrification was performed by immersing the second and third sections of the straws in a water bath at $20{ }^{\circ} \mathrm{C}$ for $10-15 \mathrm{sec}$. The cryoprotective solution was removed from the embryos in a two step dilution procedure at room temperature $\left(20-25^{\circ} \mathrm{C}\right)$. Embryos suspended in the final vitrification solution were released into a culture dish containing $1 \mathrm{ml}$ of $0.33 \mathrm{M}$ sucrose in PBS medium. After 5 minutes, embryos were washed twice in fresh PBS medium and morphologically scored before culture. The warmed embryos were cultured in a standard in vitro culture condition for $48 \mathrm{~h}$ in $50 \mu \mathrm{l}$ microdrops of Ham's F10 medium+ 20\% FCS (Sigma) under mineral oil (Sigma) at $38.5{ }^{\circ} \mathrm{C}$ in an incubator containing $5 \% \mathrm{CO}_{2}$ and humidified air.

\section{Statistical analysis}

Chi-squared test was used with data in the percentages. Data presented in means values were analyzed using GLM procedure in SAS ${ }^{\circledR}$ Program (1998). Significance of the differences in the results was tested by Duncan's New Multiple Range Test (Duncan, 1955).

\section{RESULTS AND DISCUSSION}

Data in Table (1) showed that all does treated with 20 or 40 eCG+40 hCG IU/kg live weight (Superovulated does) were ovulated (100\%) compared to 18 only from $21 \mathrm{GnRH}$ treated does $(85.7 \%)$. Results also showed that the number of haemorrhagic follicles (HFs) increases according to the eCG amount injected. eCG significantly $(\mathrm{P}<0.01)$ increased the number of haemorrhagic follicles as they were nearly four times in $20 \mathrm{IU} / \mathrm{kg}$ live weight $(6.7 \pm 0.52)$ and six times as many in 40 IU/kg live weight $(10.3 \pm 0.46)$ compared with $\mathrm{GnRH}$ (control group) $(1.61 \pm 0.38)$, Plate 1. These results are accordance with earlier studies by Garcia-Ximenez and Vicente (1990) who observed that superovulation treatment cause the ovulation of a high number of abnormal haemorrhagic and cystic follicles. Confirming Kennelly and Foote (1965) observations, the gonadotrophins stimulations of the ovaries which led to an increase of the number of hemorrhagic follicles may be attributable to the supra-physiological amount of gonadotrophins administrated, involving the precocious apoptosis of the granula's cells and leading to the follicles atresia. Moreover, Stradaioli et al. (1997) reported that PMSG treatment increased significantly $(\mathrm{P}<0.01) \mathrm{HFs}(9.3 \pm 3.5$ and $17.8 \pm 3.3$ in rabbits injected with 20 or 100 IU PMSG compared to $4.3 \pm 3.1$ in the control group). Gosselin et al. (2000) explained that the administration of exogenous gonadotrophins decreases the frequency and the amplitude of the pulsatile endogenous LH secretion linked with an increase of estradiol and progesterone plasmatic concentrations. As the estrogen concentration increases, the LH concentration decreases and would become inadequate to activate the positive feedback of the estradiol on the LH secretion by the hypothalamus during the preovulatory period. Further, the absence of estrogens' positive feedback was underlined by Bakker and Baum (2000) to explain the absence of spontaneous ovulation in induced ovulators. Thus, the larger 
Table 1: Effect of eCG doses (superovulation) treated for doe rabbits on ovarian response, morphologically normal embryos recovered 48-50 h post artificial insemination and in vitro development post-thawing.

\begin{tabular}{|c|c|c|c|c|}
\hline \multirow[t]{2}{*}{ Items= } & \multirow{2}{*}{$\begin{array}{l}\text { GnRH } \\
\text { (control) }\end{array}$} & \multicolumn{2}{|c|}{$\begin{array}{c}\text { eCG doses (IU/kg live } \\
\text { weight) }\end{array}$} & \\
\hline & & 20 & 40 & \\
\hline No. of artificial inseminated donors & 21 & 10 & 10 & \\
\hline Ovulated donors, $\mathrm{n}(\%)$ & $18(85.7)$ & $10(100)$ & $10(100)$ & NS \\
\hline Haemorrhagic follicles/doe $( \pm \mathrm{SE})$ & $1.61^{\mathrm{c}} \pm 0.38$ & $6.7^{b} \pm 0.52$ & $10.3^{\mathrm{a}} \pm 0.46$ & \\
\hline No. of CLs /doe $( \pm \mathrm{SE})$ & $6.56^{\mathbf{b}} \pm 1.4$ & $26.4^{\mathrm{a}} \pm 2.3$ & $29.1^{\mathrm{a}} \pm 2.3$ & ** \\
\hline Embryos+ova recovered, $\mathrm{n}(\%)^{1}$ & $118(100)^{\mathbf{a}}$ & $245(92.8)^{\mathbf{a b}}$ & $227(78.0)^{\mathbf{b}}$ & \\
\hline Embryos recovered (fertilization rate), $\mathrm{n}(\%)^{2}$ & $114(96.6)$ & $219(89.4)$ & $191(84.1)$ & NS \\
\hline No. of embryos/doe ( \pm SE) & $6.33^{\mathbf{b}} \pm 1.3$ & $21.9^{\mathrm{a}} \pm 2.1$ & $19.1^{\mathrm{a}} \pm 2.2$ & * \\
\hline Morphologically normal embryos, $\mathrm{n}(\%)^{3}$ & $111(97.4)^{\mathrm{a}}$ & $186(84.9)^{\mathbf{a b}}$ & $147(77.0)^{\mathbf{b}}$ & \\
\hline Embryos recovered at $>16$ cell stage, $\mathrm{n}(\%)^{4}$ & $79(71.2)^{\mathbf{a}}$ & $105(56.5)^{\mathbf{a b}}$ & $61(41.5)^{\mathbf{b}}$ & \\
\hline Embryos recovered at 16 cell stage, $\mathrm{n}(\%)^{4}$ & $32(28.8)^{\mathbf{b}}$ & $81(43.5)^{\mathbf{a b}}$ & $86(58.5)^{\mathbf{a}}$ & * \\
\hline Embryos diameter at $\geq 16$ cell stage $( \pm$ SE) & $137^{\mathrm{a}} \pm 3.2$ & $128^{\mathbf{b}} \pm 2.1$ & $122^{c} \pm 2.0$ & ** \\
\hline $\begin{array}{l}\text { In vitro development to blastocysts stage post- } \\
\text { thaw, } \mathrm{n}(\%)^{4}\end{array}$ & $74(66.7)^{\mathbf{a}}$ & $112(60.2)^{\mathbf{a}}$ & $61(41.5)^{b}$ & \\
\hline
\end{tabular}

$* * \mathrm{P}<0.01, * \mathrm{P}<0.05$ and NS $=$ Not significant. $\quad$ Sig. $=$ Significance

${ }^{1}$ Percentage based on the number of CLs.

${ }^{2}$ Percentage based on the total number of embryos and ova recovered.

${ }^{3}$ Percentage based on the total number of embryos recovered.

${ }^{4}$ Percentage based on the total number of morphologically normal embryos recovered.

${ }^{\mathrm{a}, \mathrm{b}}$ Values with different superscripts in the same row differ significantly $(\mathrm{P}<0.05)$.

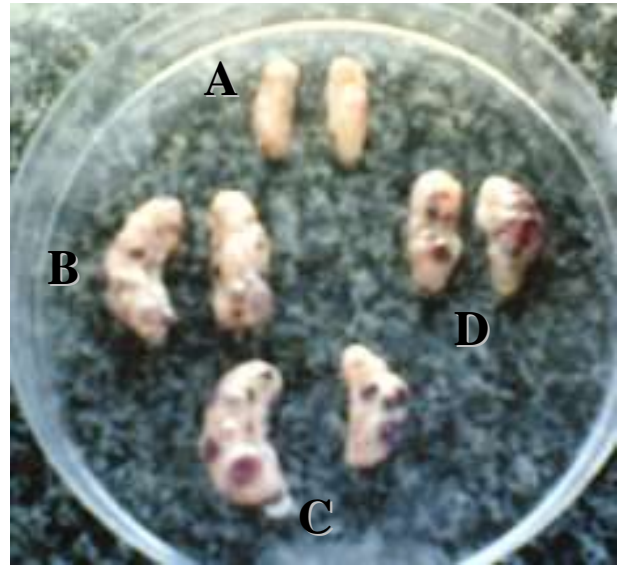

Plate 1. Ovaries of does treated with: (A) 20 $\mu \mathrm{g}$ GnRH/doe, (B) 20 eCG+40 hCG IU/kg live weight, (C \& D) 40 eCG+40 hCG IU/kg live weight. Notes the number of haemorrhagic follicles increases according to the eCG amount injected.
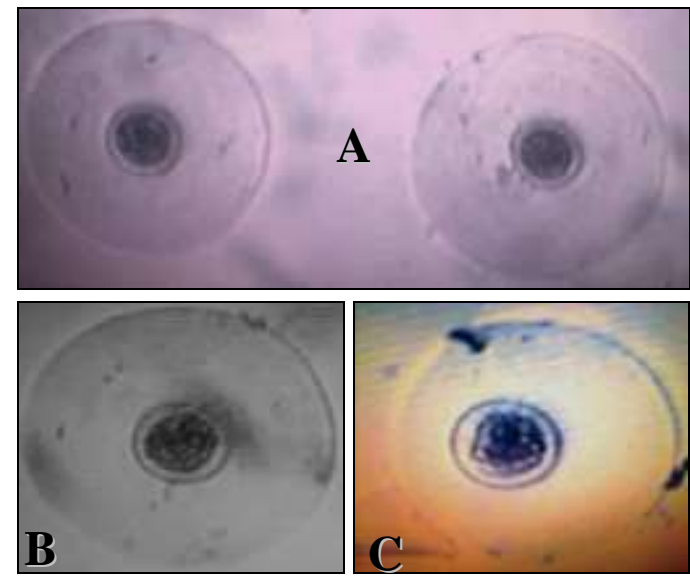

Plate 2. In vitro development of embryos vitrified-thaw to blastocysts stage collected from does treated with: $(\mathrm{A})$ $20 \mu \mathrm{g} \mathrm{GnRH/doe,} \mathrm{(B)} 20 \mathrm{eCG}+40$ hCG IU/kg live weight, (C) 40 eCG+40 hCG IU/kg live weight. 
amount of estradiol could inhibit the preovulatory pulse of LH and the ovulation mechanism. Donors treatments with 20 or 40 eCG IU/kg live weight produced significantly $(\mathrm{P}<0.01)$ more CLs upon visual inspection $(26.4$ or 29.1$)$ and yielded three to four folds embryos/doe (21.9 or 19.1) when compared with $\mathrm{GnRH}$ normally ovulated does (6.56 CLs and 6.33 embryos, Table 1). These results are comparable to those reported by Salvetti et al. (2007) who found that the number of corpora lutea and the number of embryos produced were significantly higher $(\mathrm{P}<0.001)$ in superovulated does than in control group (27.1 vs 11.9 corpora lutea and 20.3 vs 9.6 embryos produced), however, gonadotrophins administrations led to defaults of ovulation when compared with untreated does. In our study embryo and ova recovery rates were adversely affected by dose of $\mathrm{eCG}$ hormonal treatment (92.8 vs $78.0 \%$ with 20 and 40 eCG, respectively). Embryos recovered from $\mathrm{GnRH}$ normally ovulated does was significantly $(\mathrm{P}<0.05)$ reflected a higher fertilization rate $(96.6 \%)$ than those recovered from does treated with $20(89.4 \%)$ or $40(84.1 \%)$ IU eCG. Thus, it is evident that injection does with 20 or 40 eCG IU/kg live weight has increased the total number of recovered ova/embryos by induction of oocyte detachment and migration to the oviduct, but on the other hand, a concomitant lower fertilization rate was resulted. The percentage of morphologically normal (verifiable) embryos recovered from the GnRH ovulated does (control group) was significantly $(\mathrm{P}<0.05)$ higher $(97.4 \%)$ than that obtained from 20 or 40 IU eCG+hCG treated donors (superovulated group, 84.9 and $77.0 \%$, Table 1). These findings suggested that the effect of eCG may be due to an over stimulation of ovarian follicle owing to its long half-life. In general, embryo recovery and morphologically normal rate were negatively affected mainly by dose of hormonal treatment. These results are in accordance with the findings of Rebollar et al. (2000); Vicente et al. (2003); Meshreky and Salama (2005) and Fahim (2008). In earlier study, Carney and Foote (1990) gained 19.9 zygotes per donor after superovulation and $6 \%$ of which were degenerated and reported that the abnormal embryos from superovulated does had lower mitotic indices, but no obvious differences between control and superovulated does regarding embryo gross appearance were observed. Recently, Theau-clément et al. (2008) found that the percentage of the ovulation rate and the fertilizing rate and rabbit embryo survival increases with eCG dose ( 0,8 or 25 IU injected $48 \mathrm{~h}$ before insemination). In another study of goats, Holtz et al. (2012) found that the ovarian response in does treated with a high or low dose of eCG (1200 or $400 \mathrm{IU}$ ) or a low dose of pFSH (5.4 AU) was barely in excess of the ovarian response in the saline-treated controls, whereas a superovulatory dose of pFSH (16 AU) gave a satisfactory response of, on average, 14.5 ovulations (yielding 8.8 flushed ova and embryos). Also he added that eCG is less suitable than FSH for inducing superovulation in goats.

Embryos recovered at 48-50 h post insemination from $\mathrm{GnRH}$ ovulated does indicated $71.2 \%$ of embryos in >16-cell stage (early morulea) and $28.8 \%$ were in 16-cell stage compared to 56.5 and $43.5 \%$, respectively for embryos in the donor treated with $20 \mathrm{eCG}$ IU/kg live weight and 41.5 and $58.5 \%$, respectively for embryos in the donor treated with $40 \mathrm{eCG}$ (Table 1). The results reflected that eCG 
treated and dose had a significant $(\mathrm{P}<0.01$ or 0.05$)$ effect on embryo development rate. It is thus indicated that superovulation resulted in retardation of embryo development. These results are in accordance with the findings of Garcia-Ximenez and Vicente (1992) in superovulated does and Peir et al. (2004) who found that almost $76 \%$ of embryos recovered from normally ovulated high line does were in early morulae and $24 \%$ in $8-16$ cell stage. Also, he stated that the formation of the zygote and the activation of the embryonic genome occur between 25 and $48 \mathrm{~h}$ of gestation. The transition from maternal to zygotic control had been described at the 8-16 cell stages rabbit embryo (around $40 \mathrm{~h}$ after mating). At this stage, all cells were reported to be transcriptionally active and could synthesize both mRNA and rRNA. Furthermore, the transcriptionally active nucleoli appear during early morulae (Kanka, 2003). In earlier report Hawk (1988) mentioned that one possibility is that superovulation accelerates embryo transport rate resulting in their premature arrival at the uterus. In addition, the deleterious effect of transferring oviductal-stage rabbit embryos to the uterus before their normal time of entry is a well-documented phenomenon (Adams, 1979).

Embryo diameters, excepting ZP recovered from $40 \mathrm{IU}$ eCG/kg live weight treated does had significantly $(\mathrm{P}<0.05)$ smaller diameter, followed by those injected with $20 \mathrm{IU}$ eCG/kg live weight in comparison with those recovered from GnRH ovulated does (control group, Table 1). These results are in harmony with those reported by Kauffiman et al. (1998). Furthermore, Meshreky (1999) observed that average oocyte diameter collected from PMSG treated does was lower than that recovered from untreated does. Generally, treated doe rabbits with eCG/hCG (superovulation) retard the rate of embryonic development and reduced quality scores and diameter measurements. Several reports have compared qualitative and quantitative characteristics of embryos produced from superovulated and control does. Foote and Ellington (1988) postulated that in inducing superovulation embryos might be of normal morphological appearance; nevertheless, exhibit lower developmental potential than embryos from nonsuperovulated donors. Furthermore, Carney and Foote (1990) found that superovulation reduced rabbit embryo cell number (slower rates of cell division) and size compared with embryo recovered from control ovulated donors, nevertheless, the developmental potential of embryo recovered from superovulated donors does differ from that of non-superovulated does.

In vitro development of embryos vitrified-thaw to blastocysts stage were harmfully $(\mathrm{P}<0.05)$ affected by superovulation, mainly with increase dose of eCG hormonal treatment (Table $1 \&$ Plate 2). In 40 IU eCG treated does-vitrified embryos, only 61 from 147 embryo vitrified-thaw reached blastocysts (41.5\%), whereas $112 / 186(60.2 \%)$ in $20 \mathrm{IU}$ eCG treated does compared to $74 / 111$ $(66.7 \%)$ in control group. These results are in harmony with those reported by Rebollar et al. (2000) who reported that cryopreservation of rabbit embryos led to a higher rate of morphological damage when recovered from superovulated does compared with untreated one. In addition, Leoni et al. (2003) state that the higher sensitivity of embryos recovered from superovulated does to low temperatures 
leads to a decrease in their subsequent potential capacity for development after vitrification. However, recently Viudes De Castro et al. (2009) reported that the developmental potential of frozen-thawed rabbit embryos obtained from superovulation (RH-FSH alone or RH-FSH+5\% RH-LH) and control groups was similar, with an $83.5 \%$ in vitro development rate until the expanded blastocyst stage. The different between these reports and our work may be due to the different hormones and dose used.

In conclusion, does treated with eCG (superovulation) increased embryo production rate, yet rate of embryo quality, developmental potential pre-and postvitrification were adversely affected according to the eCG amount injected (40 IU eCG/kg live weight).

\section{REFERENCES}

Adams C.E. (1979). Consequences of accelerated ovum transport, including a reevaluation of Estes operation. J. Reprod. Fert., 55, 239-246.

Bakker J., Baum M.J. (2000). Neuroendocrine regulation of GnRH release in induced ovulators. Front Neuroendocrinol, 21, 220-262.

Carney E.W., Foote R.H. (1990). Effects of superovulation, embryo recovery, culture system and embryo transfer on development of rabbit embryos in vivo and in vitro. J. Reprod. Fert., 89, 543-551.

Duncan D.B. (1955). Multiple range and Multiple F. Test. Biometrics, 11, 1-42.

Fahim H.N. (2008). Some physiological and nutritional studies on rabbits. ph.D, Poultry Production Department, Mansoura University.

Foote R.H., Ellington J.E. (1988). Is a superovulated oocyte normal?. Theriogenology, 49: 111-123.

Fujimoto S., Pahlavan N., Dukelow W.R. (1974). Chromosome abnormalities in rabbit preimplantation blastocysts induced by superovulation. J. Reprod. Fert., 40: $177-181$.

Garcia-Ximenez F., Vicente J.S. (1990). Effect of PMSG treatment to mating interval on the superovuatory response of primiparous rabbits. Journal of Applied Rabbit Research, 13, 71-73.

Garcia-Ximenez, F., Vicente J.S. (1992). Effect of ovarian cystic or haemorrhagic follicles on embryo recovery and survival after transfer in hCG ovulated rabbits. Nutr. Reprod. Dev., 32: 143-149.

Gosselin N., Price C.A., Roy R., Carrière P.D. (2000). Decreased LH pulsatility during initiation of gonadotropin superovulation treatment in the cow: evidence for negative feedback other than estradiol and progesterone. Theriogenology, 54, 507-521.

Hawk H.W. 1988. Gamete transport in the superovulated cow. Theriogenology, 29, 125-142.

Holtz W., Wang X. , El-Gayar M. , Knight P.G. (2012). The effect of exogenous gonadotropins on ovarian function in goats actively immunized against inhibin. Theriogenology, 77, Jan 15 (2): 253-259.

Kanka J.(2003). Gene expression and chromatin structure in the preimplantation embryo. Theriogenology, 59: 3-19. 
Kauffiman R.D., Schmidt P.M., Rall W.F., Hoeg J.M. (1998). Superovulation of rabbits with FSH alters in vivo development of vitrified morulae. Theriogenology, 50: 1081-1092.

Kennelly J.J., Foote R.H. (1965). Superovulatory response of pre- and postpubertal rabbits to commercially available gonadotropins. J. Reprod. Fert., 9, 177-188.

Leoni G., Berlinguer F., Roseti I., Bogliolo L., Ledda S., Naitana S.(2003). Resumption of metabolic activity of vitrified/warmed ovine embryos. Mol. Reprod. Dev., 64, 207-213.

Meshreky Samia Z., Salama O.A. (2005). In vivo and in vitro rabbit embryo production and development: a comparative study. The $4^{\text {th }}$ Inter. Con. on Rabbit Prod. in Hot Clim., Sharm El-Sheikh, Egypt, 211-223.

Meshreky, Samia Z. (1999). Rabbit oocyte diameter in relation to developmental competence. $1^{\text {St }}$ International Conference on Indigenous Versus Acclimatized Rabbits, Fac. Env. Agric. El-Arish, Egypt. (7-9 Sep.,), 289-297.

Peir R., Santacreu M.A., Climent A., Blasco A.(2004). Divergent selection for uterine capacity: Early embryo mortality. $8^{\text {th }}$ World Rabbit Congress, Puebla, Mexico, (September 7-10): 121-126.

Rebollar P.G., Ubilla E., Lorenzo P.L., Sánchez-Dávil M., Sánchez J., Tucker L., Alvaiño J.M.R. (2000). Ovulation and embryo implantation rate in synchronised artificial inseminated multiparous lactating does. In: Proc.: 7th World Rabbit Congr., Valencia, Spain, Vol. A, 239-244.

Rebollar P.G., Dal Bosco A., Millán P., Cardinali R., Brecchia G., Sylla L., Lorenzo P.L., Castellini C. (2012). Ovulating induction methods in rabbit does: The pituitary and ovarian responses. Theriogenology, 77, Jan 15 (2): 292-298.

Salvetti P, Theau-Clément M., Beckers J.F., Hurtaud J., Guérin P., Neto V., Falières J., Joly, T. (2007). Effect of the luteinizing hormone on embryo production in superovulated rabbit does. Theriogenology, 67,1185-1193.

SAS. 1998. SAS/STAT User's Guide (Release 6.03). SAS Inst. Inc., Cary NC, USA.

Schmidt P.M., Hollifield V.M., Lin X., Wildt D.E. (1992). Induced ovulation and adequate embryo recoveries in New Zealand White rabbits treated with a low PMSG/HCG dose or single daily injections of FSH-P. Theriogenology, 37, 293.

Shaver E.L. 1970. The chromosome complement of blastocysts from rabbits injected with various doses of HCG before ovulation. Reprod. Fert. ,23, 335-337.

Stradaioli G.. Verini-Supplizi A., Monaci M., Canali C., Boiti C. 1997. Effects of different doses of PMSG on ovarian response and in vitro embryo development in rabbits. World Rabbit Science, 5(3): 143-148.

Theau-clément M., Lebas F., Falières J. (2008). Influence of different eCG doses on the rabbit doe ovary response, fertilizing aptitude and embryo development. World Rabbit Sci., 16, 73-79.

Vicente J.S., Viudes De Castro M.P., Garcia M.L.(1999). In vivo survival rate of rabbit morulae after vitrification in a medium without serum protein. Reprod. Nutr. Dev. , 39, 657-662. 
Vicente J.S., Viudes-De-Castro M.P., Garcia M.L., Baselga M. (2003). Effect of rabbit line on a program of cryopreserved embryos by vitrification. Reprod. Nutr. Dev., 43, 137-143.

Viudes De Castro M.P., Cortell C., Mocé E., Marco-Jiménez F., Joly T., Vicente J.S. (2009). Effect of recombinant gonadotropins on embryo quality in superovulated rabbit does and immune response after repeated treatments. Theriogenology, 72, 655-662.

\section{تأثير المعاملة الهرمونية على استجابة مبايض الأرانب و إنتاج الأجنة الطبيعية وتطور الأجنه معمليا بعد الأساله البه}

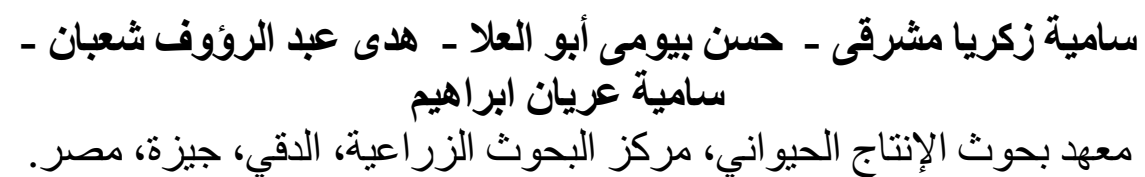

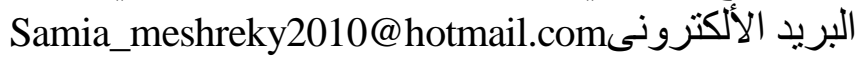

تم اختبار تأثير الجر عة المحقونة من هرمون eCG على استجابة مبايض الأر انب و إنتاج الأجنة

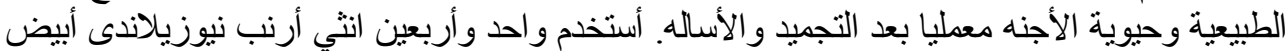

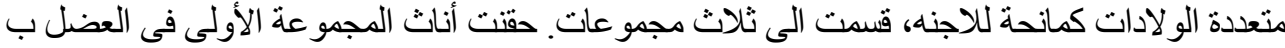

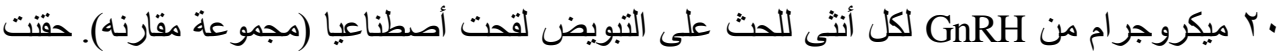

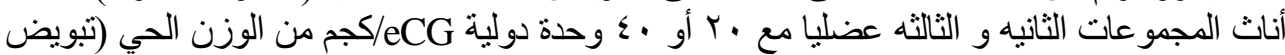

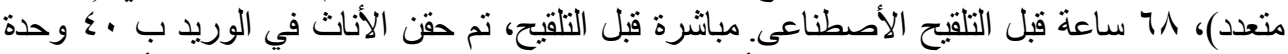

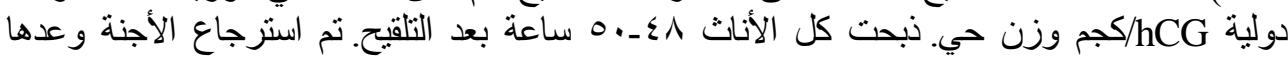

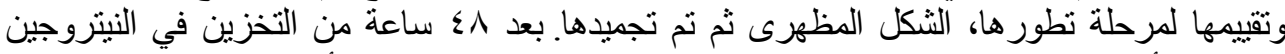

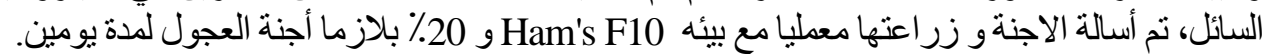

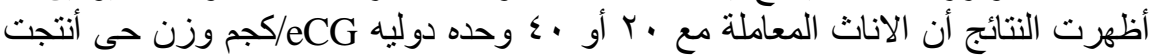

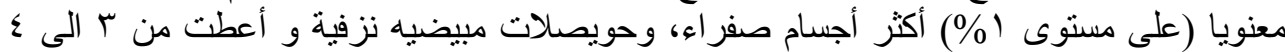

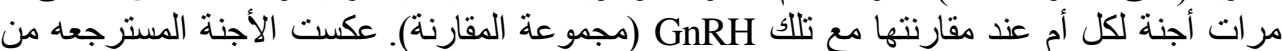

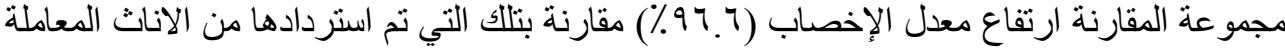

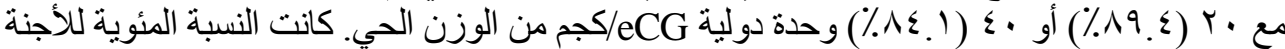

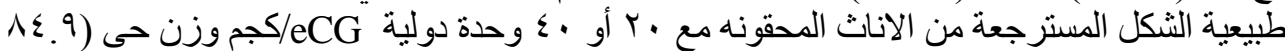

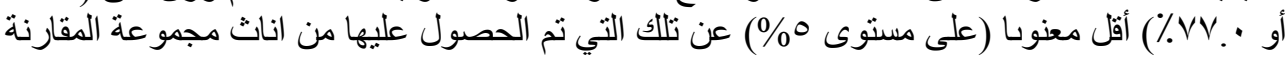

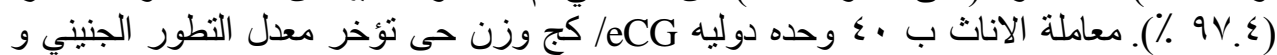

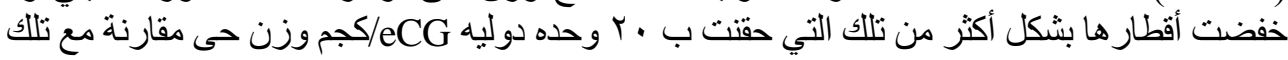

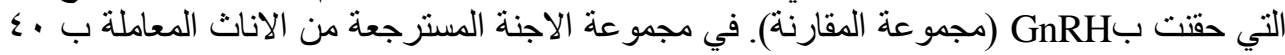

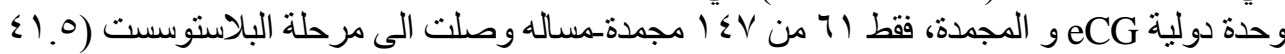

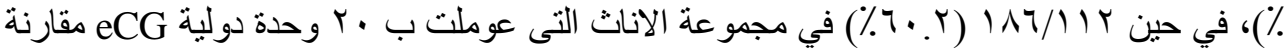

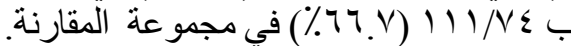

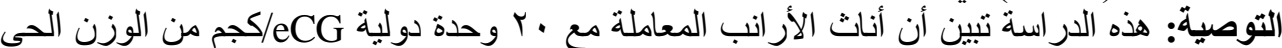

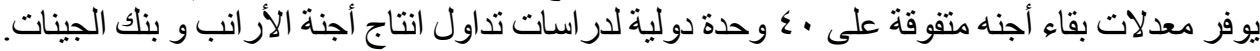

